\section{Transplant trials prove value of ITN}

The commencement of the "Edmonton Protocol" this fall at 10 centers around the world is a great illustration of what can be achieved when international scientists are prepared to collaborate and push a field of research to the next level. The protocol aims to cure diabetes by transplanting isl ets isolated from cadaver pancreata through the main portal vein into insulin-dependent diabetics (NEJM,

343, 230; 2000).

In organ transplantation, it is impossible to know if patients are tolerant without taking them off immunosuppressive drugs, which cannot be done without risking re jection. However, the protocol, in which patients are not treated with immunosuppressive glucocorticoids, represents an improved clinical system for studying tolerance induction, a therapeutic approach that would allow patients receive transplants without undergoing long-term immunosuppression.

The multicenter project is the debut initiative of the Immune Tolerance Network (ITN), an international collaborative effort to test clinical strategies to induce immune tolerance in humans. ITN was born after prominent researchers and National Institutes of Health (NIH) officials decided that not enough was being doneto test tolerance induction methods. In part, they were frustrated by a lack of understanding of tolerance induction in humans, despite great experimental success inducing tolerance in rodents. ITN director, Jeffrey Bluestone says, "If we continue only to do experiments in mice, we may never learn what the rules are in humans."

So last year, ITN contracted with NIH to act as a granting agency with complete authority to award grants for tolerance therapy research. ITN, which is funded from the National Institute for Diabetes and Digestive and Kidney Diseases, the National Institute for Allergy and Infectious Diseases and the Juvenile Diabetes Foundation International (Nature Med, 5, 471; 1999), will spend \$144 million over 7 years on tolerance therapy research in humans and expects to announce other trials in asthma and allergy, systemic lupus erythematosus and multiple sclerosis, be fore the end of 2000.

One beauty of the ITN is its decentralization: Bluestone is presently moving from the University of Chicago to the University of California at San Francisco, but the group operates by assigning administrative duties to an international network of more than 70 well-regarded tolerance investigators. Its areas of clinical interest are islet and kidney transplantation, al leviating autoimmune diseases, and controlling allergen responses in al lergy and asthma.

ITN is also funding research to develop as-

\section{NIH funds gender biology research}

Evidence that the field of gender biologyresearch into the biological differences be tween males and females-is a growing area of scientific investigation has been backed up by the US National Institutes of Health (NIH) announcement that it has inaugurated a $\$ 5.5$ million program to study women's health issues.

The program, Building Interdisciplinary Research Careers in Women's Health (BIRCWH), comprises 11 participating American universities that will each receive $\$ 500,000$ to recruit a minimum of four re search scholars-three of which must be clinicians. Junior faculty members sel ected as Interdisciplinary Women's Health Research Scholars will be matched with a senior investigator who will mentor them for two to five years.

Program co-ordinator, Donna Vogel, Associate Chief for Clinical Research at the National Institute of Child Health and Human Development (NICHD) which cosponsors the program with the Office of Research on Women's Health (ORWH), explains that BIRCWH will target multidisci- says to monitor immune tolerance in individual patients, so physicianswill eventually be able to predict when tolerance has been achieved. For this purpose ITN is establishing core facilities in genomics, microarrays and other technologies to identify genes

Tom Hollon, Bethesda turned on or off by tolerancetherapies. plinary research because some conditions that affect women do not fit neatly into specific research domains. "Premenstrual syndrome is a terrific example of an interdisciplinary area," says Vogel, "It's a condition that has tremendous morbidity but falls in between institutes, so it might be worked on by National Institute of Mental Health and by NICHD, and now the ORWH can fund collaboration between the two." She hopes that this type of integration of women's health research will become the norm as opposed to the fragmentation of efforts that has gone before.

ORWH may also soon bein a position to distribute funds for environmental factors that affect women's health if a bill currently making its way through Congress succeeds. Proposed by Congresswoman Louise Slaughter (D-NY), the bill will award a total of $\$ 4$ million to six centers "whose purpose is conducting multidisciplinary research on environmental factors that may be related to the development of women's health conditions."

\section{Karen Birmingham, London}

\section{UK approves human stem cell research}

More than a year later than promised, the British govemment last month released a report compiled by an expert group headed by Chief Medical Officer, Liam Donaldson, on the potential medical benefits of human stem cell research and cell nuclear replacement [cloning]. To the relief of the intemational scientific community, the report finds in favor of allowing experimentation on human embryos for the purpose of stem cell research (Nature Med. 5, 855; 1999).

The government has accepted the report's recommendations and a positive vote in the Houses of Parliament this fall should ensure that appropriate changes are made to the Human Fertilisation and Embryology Act (HFEA) of 1990. Although the use and creation of human embryos is already permitted under the 1990 Act for five specific research purposes, the amendment for stem cell exploration will be the first technique approved that is not related to human reproductive research. The Government continues to regard the cloning of human beings as "ethically unacceptable" and will bring forward legislation to make reproductive cloning by the cell nuclear replacement technique a criminal offense.

The government is now asking its Research Councils, which include the Medical Research Council, to establish stem cell research programs as a priority "focusing on the derivation of stem cell lines from all sources (including embryos), the production of stem cell lines by cell nuclear replacement, reprogramming the somatic cell nucleus to derive stem cell lines and the differentiation of stem cell lines for therapeutic purposes."

Karen Birmingham, London 